\title{
Agreement on Strategic Partnership between the Islamic Republic of Afghanistan and the Republic of India
}

The Islamic Republic of Afghanistan and the Republic of India, hereinafter referred to as "the Sides",

RECOGNISING the time-tested and friendly relationship between the two countries, underpinned by historical and cultural ties;

EMPHASISING the fundamental and lasting importance of the Treaty of Friendship between the Government of India and the Royal Government of Afghanistan of 4 January 1950, and subsequent Agreements and Joint Statements;

PROCEEDING from a desire to further strengthen their traditional and historical ties to mutual benefit;

DRAWING upon their rich and fruitful tradition of cooperation in various fields since the establishment of their diplomatic relations;

CONVINCED that the further comprehensive development of their bilateral ties would promote progress and prosperity in both states and the region as a whole;

APPRECIATING the significant expansion of bilateral ties between the two countries and, in this context, the sincere and generous assistance that the Republic of India has provided to the Islamic Republic of Afghanistan over the past ten years;

SEEKING to impart a long term commitment to their multifaceted bilateral relations and to actively develop them in political, development, economic, trade, scientific, technological, cultural and other fields in the years ahead,

CONFIRMING their adherence to the common ideals of peace, democracy, rule of law, non-violence, human rights and fundamental freedoms,

REAFFIRMING their commitment to international law, including to the purposes and principles of the United Nations Charter,

Hereby proclaim the establishment of relations of Strategic Partnership, as laid out in the following paragraphs: 


\section{GENERAL PRINCIPLES}

1. This Agreement, based on mutual understanding and long term trust between the Sides, envisages the elevation of the multifaceted ties between the two countries to higher levels, both in the bilateral field and in the international arena.

2. The Strategic Partnership between the Sides is based upon the principles of sovereignty, equality and territorial integrity of States, non-interference in their internal affairs, mutual respect and mutual benefit.

3. The Strategic Partnership between the Sides is not directed against any other State or group of States.

\section{POLITICAL \& SECURITY COOPERATION}

1. The Sides agree to engage in close political cooperation and, in this respect, establish a mechanism for regular bilateral political and Foreign Office consultations. Political consultations will be led by Foreign Ministries of both countries and include summit level consultations convened at least once a year.

2. The Sides agree to consult and cooperate at the United Nations and other international, regional and multilateral fora. Such cooperation is to be aimed at influencing decisionmaking in these fora in the interest of both countries. Cooperation at the UN and multilateral fora would include:

(a) Joint initiatives on key regional and international issues;

(b) Support for the reform and expansion of the United Nations Security Council, including a permanent seat for India in the Council.

3. The Sides agree to establish a Strategic Dialogue to provide a framework for cooperation in the area of national security. The Dialogue will be led by NSAs and involve regular consultations with the aim of intensifying mutual efforts towards strengthening regional peace and security.

4. Security cooperation between the Sides is intended to help enhance their respective and mutual efforts in the fight against international terrorism, organized crime, trafficking in narcotics, money laundering and so on.

5. India agrees to assist, as mutually determined, in the training, equipping and capacity building programmes for Afghan National Security Forces.

TRADE \& ECONOMIC COOPERATION 
1. The Sides commit to strengthening trade, economic, scientific and technological cooperation, as well as cooperation between other bodies of business and industry representatives, with a view to expanding trade and economic relations;

2. In the interest of Afghanistan's sustainable development, and furthering economic interdependence between the two countries, the Sides commit to deepening and diversifying cooperation in sectors such as agriculture, rural development, mining, industry, energy, information technology, communications, transport, including civil aviation, and any other areas that the Sides may agree on.

3. The Sides agree to take effective measures to create a favourable environment to promote trade and investment. The measures shall include, among others:

(a) Enhancing investment protection;

(b) Simplifying customs and other procedures, [and] promoting the removal of non-tariff barriers, and gradually lowering tariff barriers;

(c) Work towards the creation of air-cargo facilities for promotion of commercial exchange;

(d) Cooperating in the areas of banking and finance, and improving credit and insurance facilities; and

(e) Enhancing cooperation and coordination at international trade, economic and financial bodies.

4. To achieve a sustained expansion of bilateral trade and economic ties with a long term perspective, the Sides will establish effective mechanisms for interaction between Indian and Afghan entities. Specific measures will include:

(a) Encouraging contacts between regions/provinces in both countries with a view to promoting trade, economic and cultural cooperation;

(b) Mandating the relevant bodies of countries to jointly explore the possibilities of regional trading arrangements with third countries;

(c) Further enhancing the quality and international competitiveness of their goods by, promoting cooperation between the institutions of quality assurance and standardization, and on new technologies; and

(d) Encouraging greater cooperation between the Chambers of Commerce and Industries of both countries.

5. Recognizing that regional economic cooperation is vital to the future economic prosperity of individual nations, the Sides agree to cooperate, both bilaterally and through regional organizations in promoting regional economic cooperation. Regional economic cooperation shall:

(a) Envisage assisting Afghanistan emerge as a trade, transportation and energy hub connecting Central and South Asia and enabling free and more unfettered transport and transit linkages;

(b) Focus on development of regional infrastructure projects; 
(c) Help facilitate the integration of the Afghan economy within the South Asian and global economies by opening markets for Afghan and Indian products for mutual benefit; and

(d) Strengthen regional cooperation under SAARC, of which both sides are members.

\section{CAPACITY DEVELOPMENT AND EDUCATION}

1. In the interest of Afghanistan's long-term, sustainable development, and building on the existing generous aid programme offered by India to Afghanistan, India commits to continue its assistance to the development and capacity building efforts in Afghanistan.

(a) Cooperation will, among other areas of focus, concentrate on the agriculture, mining and health sectors, reflecting Afghanistan's priorities; and

(b) India further commits to expand ongoing Small Development Projects (SDPs) for grass-root level development in the remote and rural areas.

2. The Sides agree to establish institutional linkages between their respective governments by encouraging cooperation between Ministries/agencies of two sides. India offers the experience of its own institutional, administrative, political and economic systems as references that Afghanistan can study and benefit from in the light of its own needs and realities.

3. As part of its highly successful annual scholarship programme, and the broader strategy of support to higher education for Afghanistan, India will continue to expand education and training opportunities in India through the ICCR and ITEC scholarships, and multilateralfunded programmes.

(a) Responding to the requirements of Afghanistan, India will explore avenues to expand scholarships in medical, engineering and management institutes of India; and

(b) The Sides will also encourage and facilitate annual student exchange programmes at the school and university levels.

4. As part of its capacity building support for the Afghan government, India will continue and expand technical, training and other capacity building support to the various departments in the three branches of government, including the Executive, Judiciary and the Parliament.

5. In response to Afghanistan's need to strengthen its administration and governance at national and sub-national levels, India offers its experience of governance at the national, state, district and local body levels, and technical assistance in setting up a permanent, career-based civil service suitable for Afghan realities. 


\section{SOCIAL, CULTURAL, CIVIL SOCIETY \& PROPLE-TO-PEOPLE RELATIONS}

1. In pursuit of further expanding the people-to-people bonds that exist between the two countries, the Sides envisage greater exchanges between parliament, media, women, youth, sports, academic, cultural, intellectual and religious figures and bodies.

2. Through the India-Afghanistan Foundation, the Sides will seek to promote social and cultural ties, with a focus on arts, literature, poetry and so on, and further expand the exposure to each others' cultural heritage and achievements.

3. The Sides will encourage and promote greater exchanges between media organizations in their respective countries, within the framework of an independent and free media.

4. Both Sides will work for the upliftment of women, their education and rights, and also for the poorer or weaker sections of their societies.

5. To encourage and expand interaction and legitimate movement of people between the two countries, the Sides agree to simplifying rules and procedures for travel by citizens of both countries. The Sides intend to:

(a) Promote tourist exchanges and cooperation between tourist organizations in both countries; and

(b) Encourage sister-city agreements between the cities/provinces/states of the two countries.

6. To facilitate legal cases involving nationals of one country in the other, the Sides will work towards agreements on mutual legal assistance in civil and criminal matters.

7. To promote relations between civil societies and, in particular, enable intellectual exchanges, the Sides intend to establish India-Afghanistan Round Table consisting of eminent persons representing different fields.

8. Both Sides agree to promote cooperation and exchanges in the field of sports.

9. Both sides agree to share and learn from each others' experience of the values and institutions of democracy, including the sharing, distribution and devolution of powers, relations between the Centre and States/Provinces, electoral reforms etc.

10. The Sides agree to establish parliament-to-parliament exchanges between the two countries by organizing visits of parliamentary delegations and establishing parliamentary friendship groups in the two countries. 


\section{IMPLEMENTATION MECHANISM}

1. This Strategic Partnership would be implemented under the framework of a Partnership Council, which will be headed by the Foreign Ministers of both countries. The Council will convene annual meetings.

2. The Council will consist of separate Joint Working Groups on Political \& Security Consultations, Trade and Economic Cooperation, Capacity Development \& Education, and Social, Cultural and Civil Society, involving high level representatives from concerned Ministries/Authorities.

3. The existing dialogue mechanisms between the two sides will become part of the Council.

\section{CONCLUSION}

The Islamic Republic of Afghanistan and the Republic of India go forward in this partnership, re-asserting the fundamental and lasting spirit of the Treaty of Friendship between the Government of India and the Royal Government of Afghanistan of 04 January 1950, which states: "There shall be everlasting peace and friendship between the two Governments who will further strive to maintain and strengthen the cordial relations existing between the people of their respective countries.”

Signed on the $4^{\text {th }}$ October 2011 at New Delhi in two originals, each in Hindi, Pashto, Dari and English languages.

President

of the Islamic Republic of Afghanistan
Prime Minister

of the Republic of India 